\title{
Her Majesty's Ships Erebus and Terror and the Intersection of Legal Norms
}

\author{
Nigel Bankes*
}

\begin{abstract}
This article examines three main bodies of law that apply to the discovery of Her Majesty's Ships Erebus and Terror. These ships set sail from England in 1845, became trapped in ice in what is now the Canadian Arctic Archipelago, and were not re-discovered until 2014 and 2016. Public international law is relevant to the inquiry insofar as this body of law deals with immunity claims with respect to warships and state-owned ships and property, and also establishes the rights of the coastal state with respect to the various maritime zones and activities within those zones. The UNESCO Convention of $200 \mathrm{I}$ on the Protection of the Underwater Cultural Heritage is also relevant when considering the rights and obligations of states with respect to sunken vessels. In addition to the general body of public international law, the article also examines three bilateral agreements between the United Kingdom of Great Britain and Northern Ireland and Canada with respect to the wrecks. These agreementspart treaty, part private law arrangements-form a second specialized body of relevant law. The final part of the article examines how the status of the vessels is also governed by the terms of the Nunavut Land Claims Agreement between Canada and the Inuit of Nunavut, the source of the third body of relevant laws.
\end{abstract}




\section{Introduction}

Her Majesty's Ships Erebus and Terror set sail on May 19, 1845, from the port of Greenhithe, on the estuary of the Thames, England. The vessels were under the command of Sir John Franklin with a complement of 129 officers and men. Their mission was to discover the Northwest Passage, to transit the passage, and then to return to England via the Pacific. There are detailed accounts of the fate of the expedition ${ }^{1}$ but the following provides a succinct summary of the fate of the two ships and their crew:

The last European contact with HMS Erebus and HMS Terror was in August 1845 by two whaling vessels. There were further encounters with Inuit groups, after which, the crews were never seen again. The disappearance of Franklin's crew set off a massive search effort in the Arctic and the broad circumstances of the expedition's fate were not revealed until 1859 when a vessel chartered by Lady Jane Franklin learned that both ships had become trapped in ice in late 1846 and had remained so for approximately one year and a half. Franklin had died on June 11,1847, the complement of both ships had perished, and HMS Erebus and HMS Terror were lost to the ice. The general vicinity of the two vessels was learned, but not their specific location. ${ }^{2}$

The many searches for the vessels over the decades and centuries culminated in six Parks Canada-led searches beginning in 2008, which resulted in the discovery of HMS Erebus in September 2014 and HMS Terror in September 2016 (see Figure 1). ${ }^{3}$ It is widely acknowledged that Inuit knowledge was instrumental in the ultimate discovery of the precise location of these wrecks. ${ }^{4}$

The voyages of the Erebus and Terror occurred at a particular moment within the evolution of Empire. They were undertaken within a territory that was poorly known to the English Crown but likely considered by the Crown to be terra nullius, that is to say, lands that could be claimed by the English Crown. ${ }^{5}$ Yet this area of marine space (and ice), however, was neither unknown to, nor unclaimed by, the Inuit inhabitants of the area where the vessels found themselves trapped. ${ }^{6}$

The discovery, celebrated for many reasons, serves to bring into sharp focus the question of which law or laws (including different systems of law) are relevant with respect to issues such as the protection and ownership of the vessels and the wreck sites. This turns out to be a more complicated question than might 
be expected by a general observer, or even by a lawyer with general training in domestic law. This is because the resolution of the legal issues associated with the ownership of, and responsibility for, these two shipwrecks involves questions relating to different normative orders: (1) public international law; (2) the terms of specific agreements relating to the wrecks between the United Kingdom (UK) and Canada whether operating in public international law or private law; and (3) Canadian law, including the terms of the Nunavut Land Claims Agreement between Canada and the Inuit of Nunavut, ${ }^{7}$ as well as federal laws protecting historic and cultural sites. This article has the modest goal of attempting to provide a descriptive account of these bodies of relevant law and takes these three bodies of law as its outline.

\section{Public International Law}

Public international law is the body of law governing the relationship between states. Within general public international law there are at least two bodies of norms that are relevant to our inquiries. The first concerns the laws pertaining to the legal status of warships (even when they have lost their naval or any other capability) or state-owned ships and the claims to immunity associated with that status. The second concerns the body of international law that addresses the protection of underwater cultural heritage. This body of law finds its most authoritative expression in the 2001 UNESCO Convention on the Protection of Underwater Cultural Heritage (UCH Convention). ${ }^{8}$ The interaction between these two bodies of law is complex although recent work by the Institut de droit International (IDI) ${ }^{9}$ on the Legal Regime of Wrecks of Warships and Other State-Owned Ships in International Law has done much to clarify the issues. The IDI's work culminated in the adoption of an illuminating resolution on the subject in 2015 (the Tallinn Resolution). ${ }^{10}$ The resolution comprises a preamble and fifteen articles. The background materials to the resolution include a preliminary report prepared by the IDI's rapporteur, Natalino Ronzitti, as well as the discussion and proposals from other IDI members. ${ }^{11}$ 
WRECKS OF HMS EREBUS AND HMS TERROR NATIONAL HISTORIC SITE OF CANADA LIEU HISTORIQUE NATIONAL DU CANADA DES ÉPAVES-DU-HMS-EREBUS-ET-HMS-TERROR

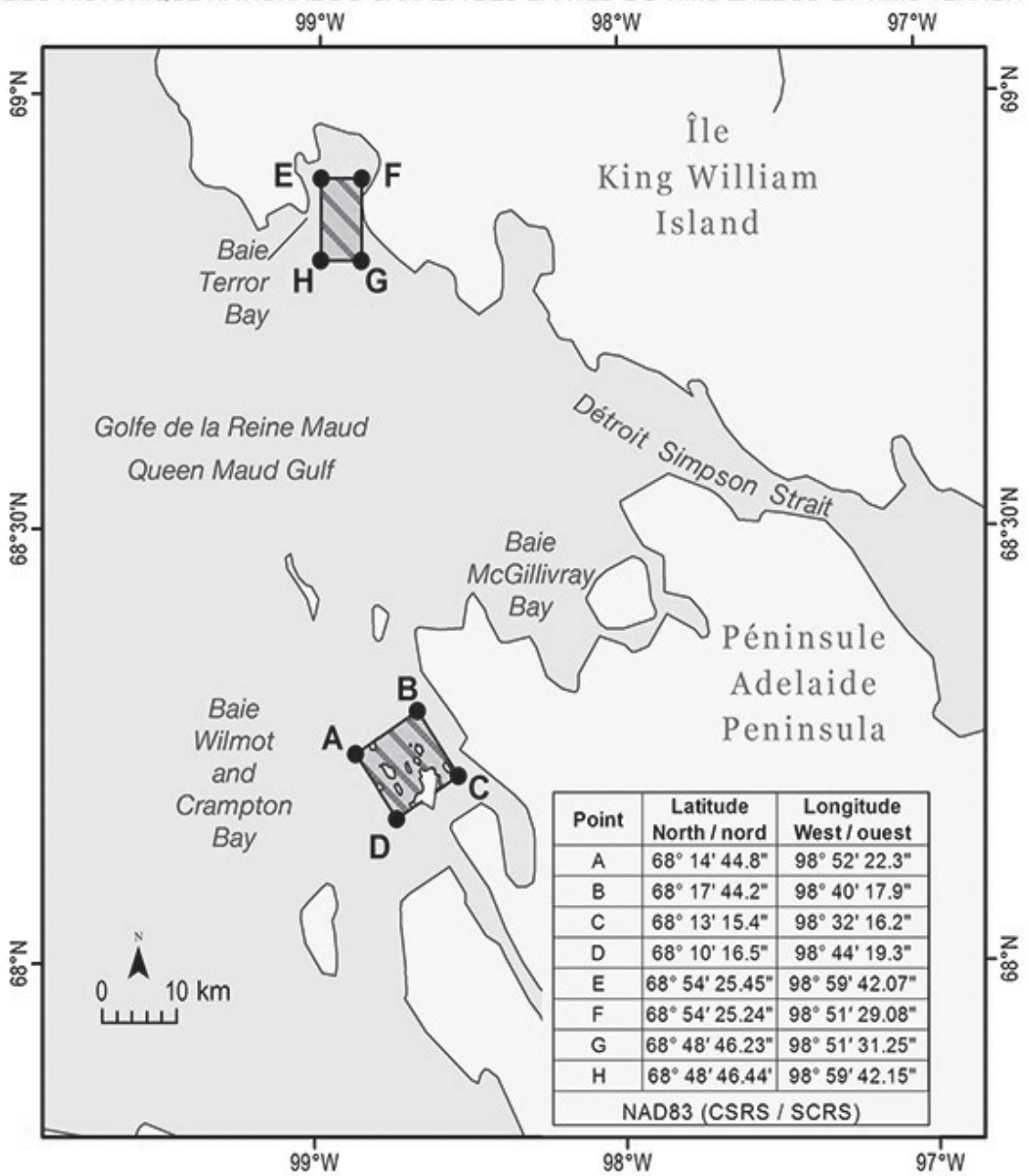

Figure I. Location of the wrecks of HMS Erebus and Terror. Source:"Wrecks of HMS Erebus and HMS Terror National Historic Site: Superintendent's order," National Historic Sites, Parks Canada, online: <https://www.pc.gc.ca/en/lhn-nhs/nu/epaveswrecks/info/plan>. Reprinted with permission of Parks Canada. 


\subsection{The Immunity of HMS Erebus and HMS Terror as Ships of War or State- Owned Ships}

Both HMS Erebus and HMS Terror were warships or at least state-owned ships at the time that they became stranded in ice and subsequently sank. ${ }^{12}$ They sank in waters that were adjacent to land territory that the Imperial Parliament at Westminster would at the time have regarded as being under the sovereignty of the Crown. ${ }^{13}$ The Imperial Crown subsequently transferred the Arctic Islands to Canada in $1880 .{ }^{14}$ Canada emerged as an independent state sometime after the end of the First World War but there is good reason to think that the Erebus and Terror would have been entitled to immunity against Canada and that the United Kingdom would have continued as the owner of the vessels. ${ }^{15}$ These claims are canvassed briefly in the next paragraphs and in the next section.

The sovereign immunity of warships to the enforcement jurisdiction of the adjacent coastal state is recognized in both customary and conventional international law. ${ }^{16}$ It is reflected in various provisions of the United Nations Convention on the Law of the Sea (UNCLOS),${ }^{17}$ the International Convention for the Unification of Certain Rules of Law Relating to Assistance and Salvage at Sea, ${ }^{18}$ the United Nations Convention on Jurisdictional Immunities of States and their Property, ${ }^{19}$ the Nairobi International Convention on the Removal of Wrecks, ${ }^{20}$ and the International Convention on Salvage of $1989 .{ }^{21}$

Although there is a significant debate in the literature as to the continuing immunity of a sunken warship (since it can no longer function as a vessel let alone as a military vessel), ${ }^{22}$ the final resolution adopted unanimously by the IDI strongly reaffirmed the proposition of continuing immunity. Article 3 of the agreed text proclaims that:

Immunity of sunken State ships

Without prejudice to other provisions of this Resolution, sunken

State ships are immune from the jurisdiction of any State other than the flag State.

This immunity also extends to any cargo on board the state ship. ${ }^{23}$

\subsection{The HMS Erebus, the HMS Terror, and their Cargoes as Property}

The foundering of a vessel does not in and of itself cause any loss of property in the vessel or its cargo, or any change in ownership of the vessel or its cargo. This principle of the continuity of ownership applies whether the vessel is state owned or privately owned. ${ }^{24}$ If the vessel is privately owned, ownership may come to be affected by generally applicable laws pertaining to prescription or to the law of 
finds. ${ }^{25}$ The law of salvage may also be relevant. Which law is applicable may be determined by private international law (i.e., conflict of laws). ${ }^{26}$ The IDI's analysis supports this conclusion with respect to the vessel itself as well as its cargo:

Article 4

Sunken State ships as property of the flag State

Sunken State ships remain the property of the flag State, unless the flag State has clearly stated that it has abandoned the wreck or relinquished or transferred title to it.

Article 5

Status of the cargo

1. Cargo on board sunken State ships is immune from the jurisdiction of any State other than the flag State.

2. Cargo owned by the flag State remains the property of that State.

3. Cargo owned by other States remains the property of those States.

4. The sinking of a ship has no effect on property rights concerning cargo on board. However, cargo may not be disturbed or removed without the consent of the flag State. ${ }^{27}$

It is evident from the formulation adopted in Article 4 that the IDI favoured the need for express abandonment with respect to state-owned ships. ${ }^{28}$

\subsection{The HMS Erebus and the HMS Terror as Underwater Cultural Heritage}

As well as being warships and state-owned ships, the Erebus and Terror also constitute underwater cultural heritage (UCH). In thinking about the law of $\mathrm{UCH}$ it is useful to begin with the provisions of UNCLOS before turning to the more specialized norms of the UCH Convention.

\subsubsection{The United Nations Convention on the Law of the Sea and Underwater Cultural Heritage}

UNCLOS has comparatively little to say about UCH and what it does have to say is not very useful. ${ }^{29}$ Article 303, one of the "general provisions" of Part XVI, provides as follows: 
Archaeological and historical objects found at sea

1. States have the duty to protect objects of an archaeological and historical nature found at sea and shall cooperate for this purpose.

2. In order to control traffic in such objects, the coastal State may, in applying article 33, presume that their removal from the seabed in the zone referred to in that article without its approval would result in an infringement within its territory or territorial sea of the laws and regulations referred to in that article.

3. Nothing in this article affects the rights of identifiable owners, the law of salvage or other rules of admiralty, or laws and practices with respect to cultural exchanges.

4. This article is without prejudice to other international agreements and rules of international law regarding the protection of objects of an archaeological and historical nature.

The scope of the Article is limited. Paragraph 1 establishes a general duty to protect and cooperate but it lacks any specific content. The reference in paragraph 2 to Article 33 is a reference to the prescriptive and enforcement powers of the coastal state with respect to the contiguous zone, which powers are limited to customs, fiscal, immigration, or sanitary laws. ${ }^{30}$ Paragraph 3 is a savings clause with respect to the rights of others including the rights of owners and salvors but the source of those rights is necessarily found outsided UNCLOS. ${ }^{31}$ Paragraph 4 is an additional savings clause with respect to other more specialized norms pertaining to UCH. This paragraph does not serve to incorporate these referenced norms within UNCLOS-it merely indicates that UNCLOS is not intended to trump those norms even though it may be the later instrument. ${ }^{32}$

In addition, Article 149 which applies to "the Area" ${ }^{33}$ stipulates that:

Archaeological and historical objects

All objects of an archaeological and historical nature found in the Area shall be preserved or disposed of for the benefit of mankind as a whole, particular regard being paid to the preferential rights of the State or country of origin, or the State of cultural origin, or the State of historical and archaeological origin.

As Bowman observes, this provision is far from satisfactory. ${ }^{34}$ It lacks a clear definition of the objects that are covered by the article, it creates the dichotomy of disposal or preservation with no middle ground, and it fails to establish any ranking or hierarchy as between the "preferential rights" of a number of different states. ${ }^{35}$ 


\subsubsection{The UNESCO Convention on Underwater Cultural Heritage}

The most important instrument dealing with underwater cultural heritage is the 2001 UNESCO Convention (the UCH Convention or Convention). ${ }^{36}$ This Convention entered into force in 2009 and while it has a growing number of parties (61 as of April 201937) neither Canada nor the United Kingdom is a party. ${ }^{38}$ The Convention defines $\mathrm{UCH}$ as "all traces of human existence having a cultural, historical or archaeological character which have been partially or totally under water, periodically or continuously, for at least 100 years" and goes on to provide examples including "vessels ... or any part thereof, their cargo or other contents, together with their archaeological and natural context." 39

The Convention aims "to ensure and strengthen the protection of underwater cultural heritage." ${ }^{40}$ Important ideas and principles underlying the Convention include the idea that UCH should be preserved for the benefit of humanity ${ }^{41}$ the principle that the in situ preservation of $\mathrm{UCH}$ "shall be considered as the first option before allowing or engaging in any activities directed at this heritage," ${ }^{42}$ and the principle that $\mathrm{UCH}$ should not be commercially exploited. ${ }^{43}$ The Convention deals with $\mathrm{UCH}$ resources in each of the maritime zones recognized by UNCLOS although for present purposes we can focus on provisions of the Convention that fall under the sovereignty of the coastal state given the location of these two wrecks. ${ }^{44}$ Article 7 deals compendiously with UCH in internal waters, archipelagic waters, and the territorial sea. Article 7(1) recognizes that within these waters "States Parties ... have the exclusive right to regulate and authorize activities directed at underwater cultural heritage."

While Article 7(1) offers an expansive statement as to the exclusive rights of the coastal state it must be read ${ }^{45}$ subject to Article 2(8), which is effectively a savings clause with respect to sovereign immunity with respect to state vessels and aircraft. ${ }^{46}$ For Ronzitti this is an example of constructive ambiguity in the drafting of a multilateral agreement, ${ }^{47}$ but for some states (such as the United States, Russia, and the United Kingdom) it represented an inadequate recognition of state rights with respect to their warships and state vessels. ${ }^{48}$

The statement of coastal state rights in Article 7(1) is also qualified by Article $7(2)$, which insists that states parties "shall require that the Rules be applied to activities directed at underwater cultural heritage" in these waters. The rules referenced here are those annexed to the Convention as an integral part thereof. ${ }^{49}$ The rules establish standards to be observed by those considering or engaged in activities directed at $\mathrm{UCH}$. The fifteen parts of the rules deal with such things as general principles (e.g., priority accorded to in situ preservation ${ }^{50}$ and ideas of proportionality ${ }^{51}$, project design, ${ }^{52}$ competence and qualification, ${ }^{53}$ conservation and site management, ${ }^{54}$ and reporting ${ }^{55}$ and curation of project archives. ${ }^{56}$ The 
Rules draw upon and follow closely the earlier work of the International Council on Monuments and Sites (ICOMOS). ${ }^{57}$ The Rules have the same status as the Convention ${ }^{58}$ and as Dromgoole observes: ${ }^{59}$

The significance of the Annex for the Convention as a whole is difficult to overstate. The Rules ... are integral to [the Convention's] entire spirit and ethos. This is illustrated by the fact that a number of the fundamental principles of the Convention are simply reiterations of the general principles of the annexed Rules.

Dromgoole goes on to emphasize that the Annex was widely praised during the negotiations even by those States that were unable to support adoption of the Convention. ${ }^{60}$

Article 7(3) specifically addresses the relationship between the coastal state and the flag state. It suggests that states parties "should inform the flag State Party to this Convention and, if applicable, other States with a verifiable link, especially a cultural, historical or archaeological link, with respect to the discovery of such identifiable state vessels and aircraft." ${ }^{11}$ For some important flag states, such as the UK, this paragraph did not adequately recognize the exclusive competence of the flag state, but Article 7(3) must also be subject to Article 2(8). ${ }^{62}$ Article 7(3) thus cannot be read as a complete statement with respect to the obligations of the coastal state with respect to sunken state vessels found within its territorial sea or archipelagic waters (or for that matter within its internal waters). There may be other relevant obligations outside the UCH Convention. The savings clause does not codify those other obligations (it was not within the mandate of the conference to do so), and as such the clause cannot provide guidance as to how to read together the jurisdictional authority of the coastal state along with the rights of the flag state based on flag state powers, the immunity of warships, and the immunity of state property. This was the gap or ambiguity that was the principal issue that the IDI sought to address in its 2015 Tallinn Resolution. ${ }^{63}$

\subsubsection{The Institut de droit International's Tallinn Resolution}

We have already dealt with some of the elements of the IDI's solution. Thus we have seen that the IDI confirms the immunity of sunken state ships (Article 3) as well as the flag state's continuing property interest in the vessel and its cargo (Articles 4 and 5). ${ }^{64}$ However, it will be recalled that the immunity of sunken state ships is said to be without prejudice "to other provisions of this Resolution." ${ }^{65}$ The implications of this become clearer when we appreciate that the resolution deals with the powers or rights of the coastal state in a parallel manner. Thus the 
resolution confirms that the coastal state has, in the exercise of its sovereignty, "the exclusive right to regulate activities on wrecks in its internal waters, archipelagic waters, and territorial sea," ${ }^{66}$ but this in turn is expressed to be "without prejudice to Article 3 of this Resolution." In sum, the coastal state may have the exclusive right to regulate activities on a state vessel in these waters but a coastal state would commit an international wrong if it exercised that authority without the consent of the flag sate of a sunken state ship. By the same token, the flag state would commit a wrong if it unilaterally engaged in operations on a state vessel in these waters without the express consent of the coastal state. There is one further qualification to this cooperative compromise that the IDI strikes in its Tallinn Resolution.

This additional qualification pertains to those situations in which the sunken state ship constitutes a threat to navigation or a threat of marine pollution. In such a case, Article 14 of the Tallinn Resolution contemplates not only that the flag state might have a duty to act (subject to the permissive authority of the coastal state with respect to internal waters, archipelagic waters, and the territorial sea) ${ }^{67}$ but also that the coastal state might have enhanced authority (or at least an immunity) if it needs to deal with such a ship. Thus, Article 14 goes on to provide that "The coastal State may take the measures necessary to eliminate or mitigate an imminent danger." ${ }^{\prime 8}$ Ronzitti clarifies the conceptual basis of this exceptional coastal state power in his commentary on an earlier draft of the resolution where he opines that the action of the coastal state "should be justified as a circumstance precluding wrongfulness, under the rationale of force majeure or state of necessity." 69

In my view, the IDI's Tallinn Resolution offers a plausible and elegant reading of the powers of the coastal state in waters over which it has sovereignty, on the one hand, and the ownership and immunity-based entitlements of the flag state of a state ship, on the other hand. The Tallinn Resolution is also consistent with the UCH Convention although less normatively prescriptive. For example, rather than expressing a preference for preservation of $\mathrm{UCH}$ in situ, the Tallinn Resolution simply suggests that wrecks of state ships should be preserved in situ "where appropriate."70

\subsection{Conclusions with respect to Public International Law}

The general rules of international law confirm that, until determined or agreed otherwise, the United Kingdom continues as the owner of the Erebus and Terror and continues to be able to claim immunity from the application of Canada's laws to those vessels. Canada would be unable to take any actions with respect to those vessels without the consent of the United Kingdom absent situations of necessity. By the same token, the UK could not search for or work on the vessels in these waters without the consent of Canada as the coastal state. Both states have a duty 
to conserve the vessels as underwater cultural heritage. Given these background rules we can now examine the practice of bilateral agreements between the UK and Canada with a view to considering how those agreements have affirmed or varied these background rules.

\section{Bilateral Arrangements}

There are at least three agreements between Canada and Great Britain with respect to the two shipwrecks. ${ }^{71}$ The first is a Memorandum of Understanding between Great Britain and Canada Pertaining to the Shipwrecks HMS Erebus and HMS Terror (the 1997 MOU). ${ }^{72}$ The second is a deed of gift executed on April 26, 2018,73 and the third is a second MOU effective on the same day as the deed of gift (the $2018 \mathrm{MOU}) .^{74}$

\subsection{The $1997 \mathrm{MOU}$}

The $1997 \mathrm{MOU}$ was evidently executed in anticipation of a program of exploration aimed at the discovery of the vessels following Canada's decision to designate the wrecks as National Historic Sites under the terms of the Historic Sites and Monuments Act. ${ }^{75}$ This designation is discussed in more detail below in section 4.1. The MOU reasserts Great Britain's continuing ownership interest in the vessels and their contents, while establishing a framework within which further exploration might occur.

It is useful to begin by considering the legal status of the MOU since there is evidently a view, shared by some, to the effect that the MOU is not legally binding. ${ }^{76}$ As I will explain below I think that this opinion is misconceived. The article then considers the substantive terms of the agreement.

\subsubsection{The Legal Nature of the MOU}

The reason why some might consider that the MOU is not binding is likely its title - a memorandum of understanding - rather than something more formal such as convention, treaty, exchange of notes, or even agreement. However, there is simply no rule of international law to the effect that an MOU cannot establish legal relations. Indeed, all of the authority is to the contrary. ${ }^{77}$ Article 2(1)(a) of the Vienna Convention of the Law of Treaties (VCLT) ${ }^{78}$ defines a treaty as "an international agreement concluded between States in written form and governed by international law, whether embodied in a single instrument or in two or more related instruments and whatever its particular designation" (emphasis added).

This MOU is clearly an agreement between states. It is signed "For the Government of Canada" by Philippe Kirsch, then the legal adviser to the Department of Foreign Affairs and International Trade, and for the Government 
of Great Britain by Sir Anthony Goodenough, then Great Britain's High Commissioner (Ambassador) to Canada. The MOU is self-evidently in writing and thus the only question is whether or not the MOU is to be "governed by international law." This boils down to the question of whether the parties intended that the arrangement should be subject to law and, in particular, international law (rather than, say, the domestic law of one or other country). The question of intent is to be determined on a manifest or objective basis, that is to say, on the basis of the words used in the text and any relevant surrounding circumstances, rather than the subjective intentions of one or both parties. ${ }^{79}$

In this case the following factors allow the conclusion that the MOU was intended to be governed by international law. First, the MOU deals with legal issues such as ownership, assignment of ownership, custody and control, agency, sovereign immunity, dispute resolution, term (i.e., duration), amendment, and means of termination. Second, the language of the agreement, while not couched in fully mandatory terms (e.g., the MOU speaks in terms of "will" rather than "shall") is certainly not hortatory. Third, the signatories to the MOU routinely have the authority to enter into binding legal relations on the part of a state (by contrast, for example, with, say, the head of a scientific agency). And fourth, given the background rules of international law canvassed in Part 3 of this article, there is a very strong sense in which the parties needed an agreement that was binding in international law because, as we will see, the terms of the MOU vary those background rules in order to provide consent to Canada to work on the wrecks once found. The only feature that points in the other direction is the choice of title (i.e., MOU rather than "agreement" or more formal denomination); but as already noted this cannot be accorded much if any weight given the VCLT's definition of a treaty. In my view, therefore, the $\mathrm{MOU}$ is a treaty for the purposes of international law and creates rights and obligations for both Canada and Great Britain. As a treaty, the MOU must be performed in good faith ${ }^{80}$ and should be interpreted in accordance with the rules on the interpretation of treaties in Articles 31-33 of the VCLT.

There is one contingent caveat to this conclusion and that is if each of Canada and the United Kingdom signalled in some authoritative way that they each regarded the MOU as not legally binding. Such an understanding would effectively amend the MOU.I am not aware of any public statements to this effect and it seems to me an unlikely eventuality given the need to modify the default rules of general international law. ${ }^{81}$

\subsubsection{The Terms of the Agreement}

The MOU has ten paragraphs. The first aims to ensure the commemorative integrity of the wrecks through "the orderly and scientific exploration, recovery 
and disposition of the wrecks and their contents. Proper archaeological research and disclosure shall prevail over financial gain and media coverage." The second paragraph recognizes that Great Britain is the owner of the wrecks but assigns custody and control of the wrecks and their contents to Canada and further acknowledges that Canada is Britain's agent for the purposes of the MOU. As such "Britain does not waive ownership or sovereign immunity with respect to the wrecks or their contents while they are on the seabed," but by the same token Britain recognizes "that any site investigation, excavation or recovery ... will be under Canada's control." ${ }^{\prime 2}$

Paragraph 3 recognizes that Canada may have a broad discretion with respect to activities in relation to the wrecks and may deny access to the wrecks; but in granting permission for investigation, exploration, or recovery, Canada undertakes to do so only to "approved organizations or persons in accordance with an approved plan or procedure." ${ }^{83}$

Paragraph 4 is only triggered if and when either of the wrecks is positively identified and discovered — at which time Britain undertakes to assign to Canada "ownership of everything recovered from the wreck and its contents" subject to two exceptions. The first exception relates to gold: any gold recovered from the wrecks (unless privately owned) is to be equally divided between Canada and Britain. ${ }^{84}$ The second exception relates to any recovered artifacts that Britain identifies as being "of outstanding significance to the Royal Navy." Canada agrees to offer such artifacts to Britain for display in an appropriate museum - in which case Britain will assume responsibility for the reasonable costs "associated with the recovery, conservation and transportation of such artifacts." ${ }^{\$ 5}$

Under paragraph 5, Canada commits to ensure that any recovered contents are dealt with in accordance with Canadian law and a plan and procedure developed by marine archaeologists of the Government of Canada, and properly conserved and displayed. British historians and archaeologists are to be accorded reasonable access for research purposes. And in paragraph 6 Canada agrees to ensure that anyone dealing with the wreck or its contents will treat both "reverently, and refrain from disturbing or bring to the surface, any human remains ...." ${ }^{16}$ Human remains that have to be removed or are inadvertently recovered are to be "re-interred with proper respect and reverence, and in consultation with Britain." ${ }^{\text {87 }}$

In the final four paragraphs Canada undertakes to keep the UK apprised of any developments ${ }^{88}$; the parties agree to consult as necessary; amendments are to be by consent of both parties; and the MOU will continue in effect from signature unless terminated by either party on thirty days' notice. ${ }^{89}$ 


\subsubsection{Observations on the $1997 \mathrm{MOU}$}

Three observations are in order. First, although the MOU predates the UNESCO Convention, and although neither Canada nor the UK have ratified that Convention, it is clear that there is considerable common ground between the Convention and its rules on the one hand, and the terms of the MOU on the other. For example, both emphasize commemorative integrity rather than profit seeking and both reference the need for approved plans for investigation and recovery, and by competent operators. On the other hand, Dromgoole asserts that this agreement and a similar agreement negotiated by the UK government in 1989 with South Africa, pertaining to HMS Birkenhead, "are manifestly out of line with the whole ethos of the Convention because they provide for the recovery and sharing of gold (treating it as a financial, rather than cultural, asset) between the governments involved." ${ }^{90}$

Second, the MOU handles the tension between continuing sovereign immunity and ownership of the vessels and its contents on the part of the UK and the rights of the coastal state (Canada) in a way that is consistent with the IDI's Tallinn Resolution. Thus, the MOU recognizes Britain's ownership of the wrecks and Britain maintains its sovereign immunity. Canada implicitly consents to both propositions. Yet at the same time, Britain recognizes that operations on the vessels will require the consent of Canada and the solution that the parties land on is to afford Canada control (i.e., through the consent afforded by the UK under the terms of the MOU) of operations with respect to the vessels.

Third, the MOU is an agreement between the two governments. There was no consultation between the Government of Canada and Inuit of Nunavut prior to the negotiation of the MOU notwithstanding the fact that the Nunavut Agreement (NA) had only been concluded several years earlier. We will return to this point in Part 5 of this article after examining the relevant terms of the Nunavut Agreement.

\subsection{The Subsequent Bilateral Agreements}

In addition to the $1997 \mathrm{MOU}$, which was negotiated before the wrecks were discovered, there are two recent agreements between the United Kingdom of Great Britain and Canada (or their ministers or agencies) dealing with the disposition of the ships and their contents. The first is a Deed of Gift between the UK's Secretary of State for Defence and Parks Canada ${ }^{91}$ and the second is an MOU between the same parties. Both are effective as of April 26, 2018. ${ }^{92}$ It makes sense to begin with the Deed of Gift since the MOU assumes the existence of the Deed of Gift and indeed builds upon its terms. 


\subsubsection{The Deed of Gift}

The Deed of $\mathrm{Gift}^{93}$ is a formal document executed under seal by the UK's Secretary of State for Defence and by Canada's Minister of Environment and Climate Change who is the minister responsible for Parks Canada. The deed is clearly intended to establish legal relations, ${ }^{94}$ for it contains a paragraph on governing law and jurisdiction stipulating that the deed "shall be governed by and construed in accordance with the laws of England and the Parties agree to submit to the exclusive jurisdiction of the Courts of England." ${ }^{95}$ But it is equally clear that the deed creates legal relations as a matter of domestic law (the law of England) and not international law. This follows not only from the provisions just quoted but also (and yet more explicitly) from paragraph 2.2, which provides that "This deed is not, and shall not be construed to be, a public law treaty." ${ }^{\prime 6}$

The deed is premised on the distinction that it makes between "Property" and the "Representative Sample of Objects." The property that is the subject of the deed is defined as the two ships and "any objects in respect of those ships" other than the Representative Sample of Objects, which are exhaustively defined as "the objects listed in Annex A." Annex A contains an enumerated list of some sixty-four objects or artifacts that have been recovered from the Erebus along with photographs of each of the items. ${ }^{97}$

Paragraph 3.1 of the deed is the granting clause in which the UK "irrevocably gifts, assigns and transfers ... the right, title and interest in and to the Property for Park's Canada's own use absolutely" but subject to the terms of the deed. The effect of excluding the representative sample of objects from the assignment and transfer must be that the UK maintains its ownership position with respect to those objects. ${ }^{98}$

The principal condition imposed by the deed with respect to the property transferred to Canada is that for a period of eighty years "the Property may only be owned by the Government and the Inuit Heritage Trust." there can be no sale, disposal, gift, lease, loan, bailment, or other transfer without the written consent of the UK. The prohibition does not apply to a "transfer within Government" (that is to say as between Canada and Nunavut) and any loan, bailment, or transfer of possession of any of the property to a third party of three years or less shall not require consent. ${ }^{100}$ Finally, and presumably given the difficulty of making promises with respect to personal property run with the property, paragraph 4.4 requires that in the event of a permitted transfer, the transferor shall "obtain from the transferee enforceable obligations which are at least as extensive and binding .... to prevent the Property being further transferred without the consent" of the UK. ${ }^{101}$ 
It is not clear why the deed picks eighty years as the period within which the instrument seeks to restrain alienation. It seems unlikely that this was chosen for perpetuities since the current UK Perpetuities and Accumulations Act of 2009 specifies a perpetuity period of 125 years. ${ }^{102}$ A further puzzle is that the 2018 MOU seeks to extend the restrictions on alienation beyond eighty years (see the discussion in the next section of this article).

In addition to the provisions dealing with the property, paragraph 5 constitutes Canada's waiver of "any claim to any award or compensation, in salvage or otherwise, in respect of the Representative Sample of Objects."

The 2018 MOU contains more elaborate provisions with respect to the disposition of the representative sample and it also contains additional references to the Inuit Heritage Trust.

\subsubsection{The $2018 \mathrm{MOU}$}

Subject to the caveat expressed above, I think that the 1997 MOU is clearly a treaty. By contrast, it is equally clear that the $2018 \mathrm{MOU}$ is not a treaty. This is because paragraph 3 of this MOU, much like the Deed of Gift, bluntly states that it "is not, and shall not be construed to be, a public law treaty." This is not the same as saying that the MOU gives rise to no legal obligations, but it must be the case that the instrument does not give rise to obligations under international law.

The MOU adopts the same definitions of representative sample of objects and the property as are contained in the Deed of Gift. The MOU contains five main groups of provisions: (1) provisions dealing with "research and recovery"; (2) a provision dealing with future loans of property; (3) provisions dealing with the representative sample of objects; (4) provisions dealing with alienation; and (5) provisions dealing with human remains.

The provisions on research and recovery ${ }^{103}$ elaborate on the standards established by the $1997 \mathrm{MOU}$ and incorporate by reference both the Annex to the UNESCO Convention (i.e., the Rules) and the standards and guidance adopted by the UK Chartered Institute for Archaeologists. ${ }^{104}$

The singular paragraph 8 deals with future loans of the property. Canada agrees to future loans of the property on the request of the National Museum of the Royal Navy "subject to the written consent of any other owner of the Property." This rather odd term "any other owner" seems designed to embrace the co-ownership interest of the Inuit Heritage Trust pursuant to the Nunavut Final Agreement (as discussed in Part 4.2 of this article).

The two paragraphs (9 and 10) dealing with the representative sample of objects further particularize the disposition of these objects. Paragraph 9 provides that the objects will be conserved and packaged to international standards by 
and at the expense of Canada and that Canada undertakes to compensate the UK for any damage caused by failing to observe these standards. Paragraph 10 indicates that Canada is to transfer the objects to the National Museum of the Royal Navy in the UK by October 31, 2019. Canada is entitled to reimbursement of its reasonable costs of transporting the objects.

Paragraphs 11-14 (under the heading of alienation) are curious insofar as they purport to extend the conditions or restrictions on alienation contained in the Deed of Gift beyond the period of eighty years. The drafting is quite convoluted especially when one considers the strict legal effect of the conditions contained in the deed. Based on the clear words of the deed, the restrictions on alienation contained in paragraph 4 of the deed simply come to an end in eighty years (i.e., 2098). Of the three provisions in the MOU dealing with restrictions on alienation, paragraph 11 serves almost as a preambular recognition of the restrictions contained in the deed but paragraph 12 obliges Canada to continue to obtain the UK's written consent to any alienation beyond government (i.e., Canada or Nunavut). Paragraph 13 similarly purports to provide that bailments and other similar arrangements for no more than three years do not require consent (as in the Deed of Gift) ${ }^{105}$ and Paragraph 14 also seeks to extend Canada's obligation to require of a transferee, in any such situation, to undertake not to further alienate the property without the UK's consent. In sum, the evident effect of these provisions is to continue to require Canada to obtain the UK's consent (subject to the same types of exceptions contained in the Deed) after the eighty year period and indeed with no apparent time limit in mind.

The final set of substantive provisions (paragraphs 15-17) is grouped under the heading "Human Remains" although paragraph 17 seems to speak more generally insofar as it provides that Canada will keep the UK "appraised on a regular basis of developments relating to the recovery of the Property." Paragraphs 15 and 16 of the 2018 MOU draw upon paragraph 5 of the 1997 MOU. Thus, paragraph 15 provides that Canada will "seek to ensure" that anybody dealing with the property "will treat reverently, and refrain from disturbing or bringing to the surface, any human remains ...." Paragraph 16 indicates that if remains are recovered they will be reinterred with proper respect and reverence in accordance with the principles contained in a UK guidance document or equivalent Canadian guidance. ${ }^{106}$ Analysis of human remains should only occur as part of a planned program of research that has some "realistic prospect of producing useful knowledge."107

We can now return to the legal status of the MOU. We know that the MOU is not an agreement or a treaty within the international legal system, but it may well still be a binding agreement within either of two potentially applicable legal systems-i.e., English law or Canadian law. In the case of the Deed of Gift, the parties clearly made an election to provide that any issues pertaining to the 
interpretation or application of that instrument should be subject to the law of England and the jurisdiction of the English courts. ${ }^{108}$ For some reason, the same parties to the MOU, in an instrument that became effective on the same date, did not make the same express election or even an opposite election (i.e., subject to the law of Canada - or a particular province or territory-and the jurisdiction of the Canadian courts). In effect, in this case the parties deliberately chose to be silent.

In order to definitively solve the question as to whether the MOU gives rise to enforceable legal obligations we would first have to resort to principles of the conflict of laws in order to assess what would be the governing or applicable law. To do that we would have to consider the forum in which the issue arose as well as the various connecting factors. ${ }^{109}$ But in this case we can take a shortcut since we can assert with some confidence that the rules with respect to the creation of a contract (and in particular the intention to create legal relations) are essentially the same in both common law Canada and England (and indeed there is much common ground on the similar question with respect to the law of treaties that we have already considered). ${ }^{110}$

In this case the MOU contains mutual promises and undertakings (although generally expressed in terms of "will" rather than the more mandatory "shall") and concerns legal questions, including such issues as the standard of care for packaging the representative sample of objects, liability for breach of that duty, and reimbursement for reasonable costs. I find it hard to believe that should one of the parties choose to sue in either jurisdiction on one of these obligations, that a competent court would accept as a defence that there was no intention to create legal relations whether the matter was considered under the laws of England or the laws of a common law province or territory. ${ }^{111}$ In sum, my preliminary view is that the MOU would be held to be a binding contract if the issue were to be litigated in either Canada or England.

\subsection{Conclusions with respect to the Bilateral Agreements}

There are now three bilateral agreements between Canada and the UK with respect to the Erebus and Terror. The principal purpose of the $1997 \mathrm{MOU}$ is to set out the modalities under which the UK would consent to operations by Canada on the wrecks. The principal purpose of the Deed of Gift is to transfer the UK's ownership interest in the vessels and their cargoes to Canada and to except out of that transfer the representative sample of objects. The UK has a continuing property interest in these objects and Canada has a duty to transport them to the UK. Both the Deed of Gift and the 2018 MOU seek to impose conditions on Canada with respect to the alienation of the property. 
There is a surprising diversity in the legal status of the three agreements. In my view: (1) the $1997 \mathrm{MOU}$ is binding as a matter of international law (it is effectively a treaty); (2) the Deed of Gift is not a treaty but the gift and the conditions associated with the gift are binding under the laws of England; and (3) the $2018 \mathrm{MOU}$ is not a treaty but is likely a contract whether that were to be determined under the laws of England or under the laws of a common law province or territory.

\section{Domestic Law}

The wrecks of the Erebus and Terror are located within Canada's internal waters, in Wilmot and Crampton Bay and Terror Bay respectively, ${ }^{112}$ within the territory of Nunavut ${ }^{113}$ and within the Nunavut Settlement Area under the terms of the Nunavut Agreement between the Inuit of Nunavut and Canada. ${ }^{114}$ The following sections deal with the treatment of the wrecks as a National Historic Site in Canadian law as well as the applicable provisions of the Nunavut Final Agreement.

\subsection{Recognition and Protection as a National Historic Site}

The site commemorating the loss of the Erebus and Terror was first recognized in Canadian law in 1992 as a National Historic Site (or place) under the terms of the Historic Sites and Monuments Act, ${ }^{115}$ well before the precise location of the wrecks was known. The opening words of the formal Description of the Historic Place in the designation would be almost comical if the loss of vessels and life were not so tragic: "It is believed that the site is located somewhere in the Canadian Arctic ...."116 Designation as a National Historic Site under this Act serves commemorative purposes but it does not itself confer any particular legal protection for the site. Hence, with the discovery of first the Erebus, and then the Terror, it became necessary to take some protective measures.

The first such step was to amend the National Historic Sites of Canada Order to include the site in the Schedule along with a $10 \mathrm{~km}$ by $10 \mathrm{~km}$ areal designation to encompass the site of the Erebus in $2015 .{ }^{117}$ This was followed by a subsequent amendment in 2017 to include a somewhat smaller area around HMS Terror. ${ }^{118}$ Unlike site recognition under the Historic Sites and Monuments Act, the National Historic Sites of Canada Order is a regulation under the terms of the Canada National Parks $A c t^{119}$ and thus comes with some teeth insofar as it makes certain sections of the Canada National Parks Act applicable to the site ${ }^{120}$ and allows the National Historic Parks General Regulations ${ }^{121}$ to apply. In addition, it allows more specific orders to be made-in this case a Superintendent's Order establishing a restricted area and activities. ${ }^{122}$ With the exception of access by Nunavut Inuit to exercise harvesting rights under the Nunavut Agreement, the Superintendent's 
Order provides that no person may access the site or engage in various activities including archaeological activities, and anchoring and diving, without the written authorization of the superintendent.

Designation under the National Historic Sites of Canada Order provides the principal protection afforded to the sites and the two vessels and their contents under Canadian law.

\subsection{The Nunavut Agreement}

The Nunavut Agreement is a land claims agreement within the meaning of s. 35 of the Constitution Act, 1982, and is therefore constitutionally protected. ${ }^{123}$ The Agreement confirms Inuit harvesting rights throughout the Nunavut Settlement Area (NSA), recognizes Inuit land ownership interests, and also establishes a series of co-management bodies dealing with such matters as wildlife, land use planning, and project impact assessment and review. The Agreement also contains provisions dealing with the creation of new parks and conservation areas as well as archaeology. The NSA includes large marine areas as well as terrestrial areas and most of the provisions of the Agreement apply to these marine areas as well as to the land. There are at least two elements to the Agreement that are significant in relation to ascertaining the legal regime that applies to the wrecks of the Erebus and Terror. The first are the provisions of the Agreement dealing with conservation areas. The decision(s) to amend the National Historic Sites of Canada Order under the Canada National Parks Act triggers the application of Article 9 of the Agreement dealing with the creation of new conservation areas, including a requirement that Canada negotiate an impact and benefit agreement with the designated Inuit organization. This in turn has implications for both Article 11, Land Use Planning and Article 12, Impact Review. The second element is that the wrecks and their contents constitute archaeological sites and specimens within the meaning of Article 33 of the agreement dealing with archaeology. The following sections examine each of these elements.

\subsubsection{The Conservation Area Provisions of the Nunavut Agreement}

Article 9 defines "Conservation Area" to mean all existing Conservation Areas listed in a schedule as well as new areas "when established under legislation." 124 Article 9 references a number of different types of conservation areas including National Historic Sites. The decision(s) to add the sites protecting HMS Erebus and then HMS Terror to the Order are sufficient to make these sites conservation areas for the purposes of the Agreement. This has several important and practical consequences. The first is that it triggers a duty on the agency responsible for the initiative to enter into good faith negotiations for the purposes of concluding an 
Inuit Impact and Benefit Agreement (IIBA) with respect to the "Conservation Area." Such an IIBA "shall include any matter connected with the proposed [conservation area] that would have a detrimental impact on Inuit, or that reasonably confer a benefit on a Nunavut-wide, regional or local basis." ${ }^{125}$ The Agreement contemplates that an IIBA should ordinarily be concluded prior to the establishment of a conservation area, but s. 9.4.1 allows that in the case of an emergency an IIBA might be "concluded forthwith upon, rather than prior to, the establishment of the protected area." 126

The Regulatory Impact Analysis Statement (RIAS) for the first amendment to the Historic Sites Order for HMS Erebus specifically relied on the need for protection on an urgent basis while at the same time emphasizing that Canada was committed to fulfilling its obligations under the Agreement. ${ }^{127}$ The RIAS for the second amendment (to include HMS Terror) noted that the relevant Designated Inuit Organization (the Kitikmeot Inuit Association, i.e., the Inuit counterparty to the proposed Inuit Impact and Benefit Agreement, IIBA) had indicated that a single IIBA should be negotiated for both sites and that Kitikmeot Inuit Association and the community of Gjoa Haven both supported the swift extension of protection to the site of HMS Terror. ${ }^{128}$ As of the time of writing the parties have yet to conclude the terms of an IIBA. Until then, the Franklin Interim Advisory Committee-composed of community members and representatives from the Kitikmeot Inuit Association, Inuit Heritage Trust, Government of Nunavut, and the heritage and tourism industry-has been advising on the management of the wrecks. ${ }^{129}$

A second related implication of the designation is that a conservation area is to be co-managed between government and Inuit, and a joint planning and management committee established. ${ }^{130}$

A third related implication is that since Articles 11 and 12 of the Nunavut Agreement apply to conservation areas, a proposal or initiative for a new conservation area requires a conformity review under the land use planning provisions (although once the Historic Sites Order is amended Article 11 ceases to apply $)^{131}$ and potentially under Article 12 as well. These provisions are elaborated on in sections 163-183 of the Nunavut Planning and Project Assessment Act. ${ }^{132}$ While the 2015 amendment to the National Historic Sites of Canada Order does not seem to have occasioned a referral to the Nunavut Planning Commission and the Nunavut Impact Review Board (NIRB), this procedure was followed for the 2017 amendment to include the site of the Terror. The Nunavut Planning Commission concluded that the proposal was not subject to the terms of any applicable plan (i.e., there is no plan in effect for this part of the Nunavut Settlement Area) and 
referred the proposal for screening by NIRB ${ }^{133}$ NIRB's screening report concluded that the project did not require further review although NIRB did recommend attaching some terms and conditions. ${ }^{134}$

\subsubsection{The Archaeology Provisions of the Agreement and Related Regulations}

Archaeological activities within Nunavut are governed by a combination of Article 33 of the Agreement and the Nunavut Archaeological and Palaeontological Sites Regulations ${ }^{135}$ passed pursuant to s. 51 of the Nunavut Act. ${ }^{136}$ The two are interrelated insofar as Article 33 of the Nunavut Agreement contemplated that government would develop policy and legislation on archaeology within the Nunavut Settlement Area with the participation of the Inuit Heritage Trust (IHT), the creation of which was called for by Part 4 of Article 33. ${ }^{137}$

All of the trustees of the Inuit Heritage Truste are appointed by Nunavut Tunngavik Incorporated (NTI) - three on the nomination of the regional Inuit organizations and one directly by NTI. ${ }^{138}$ Part 5 of Article 33 outlines the elements of a permit system for regulating archaeological activities and the Nunavut Archaeological and Palaeontological Sites Regulations ${ }^{139}$ give effect to those ideas. Article 33 applies to the marine areas of the Nunavut Settlement Area and the regulations apply to "all lands and waters in Nunavut" other than lands within a national park or lands set aside as an historic site under the Canada National Parks Act. The regulations require that no person shall engage in archaeological work without a Class 1 or Class 2 permit, which is to be acquired from a "designated agency." That term is defined in the Nunavut Agreement to refer to any one of a number of different agencies including Canadian Parks Service and the Canadian Museum of Civilization, and the same term is used in the regulations. However, as a matter of practice, the regulations are administered by the Heritage Division of the Nunavut Department of Heritage and Culture. ${ }^{140}$

It follows from this that Parks Canada's original work to identify the sites of the wrecks ought to have been permitted under these regulations. However, these regulations ceased to apply once the sites were listed in the National Historic Sites of Canada Order. From that time forward the relevant regulations are the National Historic Parks General Regulation and specifically s. 3, which creates a prohibition and permit scheme for historical resources within a national historic site (formerly known as a national historic park). ${ }^{141}$

As noted above, Article 33, Archaeology, is one of the articles of the Nunavut Agreement that applies to the marine areas of the Nunavut Settlement Area. ${ }^{142}$ The sites of the wrecks, and the vessels and their contents, constitute, respectively, archaeological sites and archaeological specimens: 
"archaeological site" means a site or work within the Nunavut Settlement Area of archaeological, ethnographical or historical importance, interest or significance or a place where an archaeological specimen is found, and includes explorers' cairns; "archaeological specimen" means an object or specimen found in an archaeological site of archaeological, ethnological or historical importance, interest or significance and includes explorers' documents;

While is it perhaps the case that the principal concern of Article 33 is with the archaeological record of Inuit, the express references to explorers' cairns and documents confirms that the Article also has broader concerns. Indeed, the interconnection between the lives of Inuit and of early explorers is expressly acknowledged in the rationale contained in the Regulatory Impact Analysis Statement for the 2017 Terror amendment to the Historic Sites Order. ${ }^{143}$

Part 7 of Article 33 deals with title to archaeological specimens and Parts 7 and 8 together deal with the disposition of those specimens. As for title, s. 33.7.1 provides that Government and the Trust "shall jointly own" all archaeological specimens found in the NSA unless they are public records, the private property of any person, or "within areas administered by the Canadian Parks Service." Once again, the exception is somewhat disconcerting. At the time of their discovery the sites of the two wrecks were not under the administration of Parks Canada. They only fell under the administration of Parks Canada when the National Historic Sites of Canada Order was amended—initially in 2015 and then again in 2017.

While that may have created some uncertainty as to title, as a matter of fact the parties (i.e., the Government of Canada and the Trust) have agreed that Parks Canada and the Trust will become joint owners of all the artifacts from the two vessels - other than those excepted out of the UK's Deed of Gift. ${ }^{144}$ The parties have recently (April 2019) concluded an MOU "detailing how the two organizations will work together to protect, study, conserve and share" these artifacts. ${ }^{145}$

As for the disposition of specimens, there are several rules. First, both the Designated Agency and the Trust must jointly consent to any long-term alienation of any archaeological specimen found in the NSA. ${ }^{146}$ Failing agreement, the matter may be referred to dispute resolution. ${ }^{147}$ Second, unless the specimen is found on Inuit-owned land, the Designated Agency shall determine disposition of the specimen ${ }^{148}$ but in doing so shall endeavour to dispose of a maximum number of specimens to institutions, such as the Inuit Heritage Trust, within the Nunavut Settlement Area. ${ }^{149}$ Third, the IHT is entitled to request possession of 
any specimens found in the NSA from any federal or territorial agency and such agency may not refuse such request unless one of the listed conditions is met (e.g., the Trust would be unable to maintain the specimen without risk). ${ }^{150}$

\subsubsection{Conclusions with respect to the Nunavut Agreement}

As this analysis shows, the Nunavut Agreement is an important part of the legal regime pertaining to the wrecks of the Erebus and Terror. Designation of the sites of the wrecks under the terms of the National Historic Sites of Canada Order requires Parks Canada to negotiate an Inuit Impact and Benefit Analysis with the Kitikmeot Inuit Association. While that IIBA is still a work in progress, it is anticipated that it will provide important economic opportunities, especially for the community of Gjoa Haven (Uqsuqtuuk) - including opportunities associated with the conservation and display in the community of artifacts recovered from the wrecks.

\section{Concluding Observations}

I remarked at the outset that the voyages of the Erebus and Terror occurred at a particular moment within the evolution of Empire. The vessels became trapped in Inuit territory caught in a time warp and a particular geography that has been through several geopolitical transformations; claimed by the Imperial Crown as territory, transferred to the Dominion of Canada (all without the consent of Inuit), and ultimately emerging as the separate territory of Nunavut within the Confederation of Canada. Throughout these changes the Indigenous peoples of the territory maintained their interests in these lands and waters and maintained their world view with respect to these territories.

Any consideration of the legal status to be accorded to these vessels therefore involves reflections on intergenerational or intertemporal law as well as intersocietal law. ${ }^{151}$ Different generations and different societies have left their marks in relation to the legal rules that apply to the Erebus and the Terror. This article has attempted to map the most important marks and legal claims. It is perhaps particularly significant that the end of the period covered by the article culminates with a moment of recognition, compromise, and deep irony. This is the moment when the Imperial Crown, having long-maintained its ownership interest in the vessels and cargoes of the Erebus and Terror, quit claims those interests to Canada. Canada in turn recognizes the legal claims embedded in the Nunavut Agreement, an intersocietal agreement, and thus vindicates an Inuit interest in these vessels as a symbol of both the principle of continuity as well as a symbol of an intercultural and intersocietal interest in these vessels of the colonial project of discovery. 


\section{Notes}

1. A recent review is Russell A Potter, Finding Franklin: The Untold Story of a 165Year Search (Montreal \& Kingston: McGill-Queens University Press, 2016). The appendix to this volume (at 221-232) provides a list of Franklin searches between 1854 and 2015. Potter's account takes us up to the discovery of the Erebus in 2014.

2. This account is from the Regulatory Impact Assessment Statement (RIAS) amending the National Historic Sites of Canada Order to include protection for site of the discovery of HMS Erebus: SOR/2015-88, 8 April 2015, online: <http://www. gazette.gc.ca/rp-pr/p2/2015/2015-04-22/html/sor-dors88-eng.html>.

3. Ibid.

4. See Russell Potter, "After 165 years, Inuit Knowledge Leads to Franklin's Wrecks”, Nunatsiaq News (3 April 2019), online: <https://nunatsiaq.com/stories/article/ after-165-years-inuit-knowledge-leads-to-franklins-wrecks/>. More generally see Potter, Finding Franklin, supra note 1, passim.

5. In Tsilhqot'in Nation v British Columbia, [2014] 2 SCR 257, 2014 SCC 44 (CanLII), online: 〈http://canlii.ca/t/g7mt9 $>$, the Supreme Court of Canada claimed (at para 69) that "The doctrine of terra nullius (that no one owned the land prior to European assertion of sovereignty) never applied in Canada, as confirmed by the Royal Proclamation of 1763." For a more complex account of the use of the term terra nullius see Andrew Fitzmaurice, Sovereignty, Property and Empire, 1500-2000 (Cambridge: Cambridge University Press, 2014).

6. On the colonial encounter in marine space generally see Robert Hamilton, "Indigenous Legal Traditions, Inter-societal Law and the Colonization of Marine Space" in Stephen Allen, Nigel Bankes \& Øyvind Ravna, eds, The Rights of Indigenous Peoples in Marine Areas (Oxford: Hart Publishing, 2019); and Andrew Lipman, The Saltwater Frontier: Indians and the Contest for the American Coast (New Haven: Yale University Press, 2015).

7. Nunavut Land Claims Agreement between Canada and the Inuit of Nunavut, 1993, hereafter Nunavut Agreement, online: Crown-Indigenous Relations and Northern Affairs Canada <https://www.rcaanc-cirnac.gc.ca/eng/1100100030601/154273874 4002>.

8. UNESCO Convention on the Protection of Underwater Cultural Heritage, Paris, 2 November 2001, 2562 UNTS Registration \# 45694 (in force 2 January 2009) [UCH Convention].

9. The IDI is a private organization of preeminent public international lawyers. The IDI has long been engaged in work on the codification of public international law. In many respects the IDI operates as a private or non-governmental version of the UN's International Law Commission. The IDI's work has no binding effect although as the work of eminent scholars and practitioners it may be treated as a subsidiary means for the determination of rules of international law in accordance with Article 38(1)(d) of the Statute of the International Court of Justice. 
10. Tallinn, 29 August 2015, online: Institute of International Law < http://www.idi-iil. org/app/uploads/2017/06/2015 Tallinn 09 en-1.pdf>.

11. The preliminary report (Ronzitti Report) and discussion are available in (2011) 74 Yearbook of Institute of International Law 134 (IDI Rhodes Session). Additional background documents and the plenary discussion pertaining to the drafting of the Resolution and its adoption at the Tallinn session are available at (2015) 76 Yearbook of Institute of International Law 269 (IDI Tallinn Session).

12. Some sources (e.g.,Potter, supra note 1) refer to them as "former warships."Regardless they were certainly operated by naval officers and crew, and royal marines, and were on state (rather than commercial) business.

13. Sir James Ross was in the area several decades earlier: "we fixed the British flag on the spot, and took possession of the North Magnetic Pole and its adjoining territory, in the name of Great Britain and King William the Fourth." As quoted in Potter, supra note 1 at 167-168. For a critical discussion of the Crown's claims to sovereignty see Kent McNeil, "Sovereignty and Indigenous Peoples in North America" (2016) 22 University of California, Davis Law Review 81, online: <https://digitalcommons. osgoode.yorku.ca/scholarly works/2642>.

14. Order of Her Majesty in Council admitting all British possessions and Territories in North America and islands adjacent thereto into the Union, dated the 31st day of July, 1880 (the Adjacent Territories Order). The operative text provides that "From and after the first day of September, 1880, all British Territories and Possessions in North America, not already included within the Dominion of Canada, and all Islands adjacent to and of such Territories or Possessions, shall (with the exception of the Colony of Newfoundland and its dependencies) become and be annexed to and form part of the said Dominion of Canada; and become and be subject to the laws for the time being in force in the said Dominion, in so far as such laws may be applicable thereto."

15. As for ownership there is nothing in the Adjacent Territories Order (ibid) that could be construed as a transfer of any personal property owned by the Crown. See in this context Sea Hunt, Inc v Unidentified, Shipwrecked Vessel or Vessels, 221 F 3d 634 ( $4^{\text {th }}$ Cir. 2000) dealing with claims to two Spanish naval frigates La Galga and Juno wrecked off the coast of Virginia in 1750 and 1802 and subsequently the subject of a salvage claim by Sea Hunt. The Fourth Circuit Court of Appeals confirmed the continuing ownership interest of Spain in the vessels and inter alia rejected an argument that Spain had abandoned its claim to La Galga when it transferred most of its New World territories to Great Britain by treaty in 1763. The Court concluded (at 644-646) that the treaty could not be read as an abandonment by Spain of its property interest in the vessel; by implication neither could it be read as a transfer of Spain's interest in the vessel. For further discussion of this important case see Sarah Dromgoole, Underwater Cultural Heritage and International Law (Cambridge: Cambridge University Press, 2013) at 147-148. Property will be lost in the event of abandonment, but abandonment will not be readily assumed. For the debate as to the need for express abandonment as opposed to implied abandonment see, 
amongst other sources, David Bederman, "Rethinking the Legal Status of Sunken Warships” (2000) 31 Ocean Development and International Law 97, online: <https://doi.org/10.1080/009083200276085>; and Mariano Aznar-Gómez, "Legal Status of Sunken Warships 'Revisited”' (2003) 9 Spanish Yearbook of International Law 61. Bederman favours implied abandonment. In this case it is fairly clear that the United Kingdom evinced a continuing interest in the fate of these vessels and thus abandonment (express or implied) would not seem to be an issue.

16. Ronzitti Report, supra note 11 at 140.

17. United Nations Convention on the Law of the Sea, 10 December 1982, 1833 UNTS 397, Montego Bay (entered into force 16 November 1994) [UNCLOS]. See in particular Articles 30, 32, and 95.

18. Convention for the Unification of Certain Rules of Law Relating to Assistance and Salvage at Sea, 23 September 1910, Brussels (entered into force 1 March 1913).

19. United Nations Convention on Jurisdictional Immunities of States and their Property, 2 December 2004, New York (not yet in force), Article 16, online: $<$ https://treaties. un.org/doc/source/RecentTexts/English 3 13.pdf>.

20. Nairobi International Convention on the Removal of Wrecks, 18 May 2007, International Maritime Organization (entered into force 14 April 2015), Article 4(2), online: <https://treaties.un.org/Pages/showDetails.aspx?objid=080000028053c3a0>.

21. International Convention on Salvage, 18 April 1989, London (entered into force 14 July 1996), 1953 UNTS \# 33479, Article 4, online: <https://treaties.un.org/Pages/ showDetails.aspx?objid=08000002800a58b3 >.

22. Some IDI members took this position in the debates; see also Dromgoole, Underwater, supra note 15 at 137; and for a recent discussion see Hayley Roberts, "The British Ratification of the Underwater Heritage Convention: Problems and Prospects" (2018) International and Comparative Law Quarterly 833 at 847-850, online: <https://doi.org/10.1017/S0020589318000210>, eventually concluding (at 850) that "It is clear that there are many possible theoretical bases for wrecked warships to retain sovereign immunity."

23. IDI Tallinn Resolution, supra note 10, Article 5(1).

24. See Dromgoole, supra note 15 at $106,113,117$.

25. For discussion of the law of finds see Liza J Bowman, "Oceans Apart over Sunken Ships: Is the Underwater Cultural Heritage Convention Really Wrecking Admiralty Law?” (2004) 42 Osgoode Law Journal 1,online:<https://digitalcommons.osgoode. yorku.ca/cgi/viewcontent.cgi article $=1388 \&$ context=ohlj $>$ at $14-16$, noting that the law of finds is triggered where the owner has abandoned the property. The premise of salvage law by contrast is that the owner maintains its claim. The salvor does not obtain title but merely a claim to compensation secured by a maritime lien.

26. Ronzitti Report, supra note 11 at 151.

27. IDI Tallinn Resolution, supra note 10, Articles $4 \& 5$.

28. See the debate between Bederman and Aznar-Gómez, supra note 15. 
29. UNCLOS, supra note 17. For discussion of the UNCLOS provisions dealing with UCH see Dromgoole, supra note 15 at 29-36, 71-76, 119-125, 176 and chapter 7. Aznar-Gómez, supra note 15 , offers the following pithy assessment (at 85) "UNCLOS regulation of the underwater archaeological sites is elusive, vague and inconclusive in critical respects."

30. The contiguous zone is a zone extending beyond the territorial sea to a maximum extent of $24 \mathrm{~nm}$ from the baselines from which the territorial sea is measured within which the coastal state may exercise the control necessary to enforce its customs, fiscal, immigration or sanitary laws. UNCLOS, supra note 17, Article 33.

31. It is particularly problematic for $\mathrm{UCH}$ that Article 303 preserves the rights of salvors insofar as the principle of salvage law is completely inimical to the idea of preserving $\mathrm{UCH}$ in place and favours profit maximization rather than conservation. See Dromgoole, supra note 15 at 38, 68.

32. See Vienna Convention on the Law of Treaties (VCLT) (opened for signature 23 May 1969, entered into force 27 January 1980) 1155 UNTS 331, Article 30, Application of successive treaties to the same subject matter.

33. The Area refers to the seabed beyond the limits of national jurisdiction. UNCLOS, supra note 17, Article 1(1)1.

34. Bowman, supra note 25 at 25-26.

35. Ibid.

36. UCH Convention, supra note 8, For general discussion of the Convention see Dromgoole, supra note 15.

37. http://www.unesco.org/eri/la/convention.asp?KO=13520\&language=E\&order=alpha

38. For detailed discussion (and refutation) of the UK's objections to the Convention see Roberts, supra note 22. Canada apparently continues to consider its position with respect to the UCH Convention. See Report of the Standing Committee of the House of Commons on Transport Infrastructure and Communities, Canada's Ocean War Graves, May 2018 at 6, online: <https://www.ourcommons.ca/Content/ Committee/421/TRAN/Reports/RP9886523/tranrp23/tranrp23-e.pdf>. The Committee did not make any specific recommendation with respect to ratification but did recommend specific legislation with respect to war graves rather than cultural heritage more generally. The Report briefly references the Erebus and Terror at 7 (in connection with historic sites) and at 12 (with respect to the UK/Canada MOU).

39. UCH Convention, supra note 8, Article 1(a).

40. Ibid, Article 2(1).

41. Ibid, Article 2(3).

42. Ibid, Article 2(5).

43. Ibid, Article 2(7).

44. Articles 9 and 10 of the Convention deal with underwater cultural heritage in the exclusive economic zone and on the continental shelf. The UNCLOS, supra note 17 , does not confer any special rights on coastal states with respect to underwater cultural heritage in these zones and accordingly as Roberts, supra note 22, notes (at 854-863) there was a concern on the part of some states to ensure that the $\mathrm{UCH}$ Convention did not support creeping coastal state jurisdiction. 
45. This is simply based on the proposition that a treaty, like a statute or a contract, must be read as a whole and not as a set of severable and distinctive articles or sections: VCLT, supra note 32, Article 31.

46. UCH Convention, supra note 8, Article 2(8) “... nothing in this Convention shall be interpreted as modifying the rules of international law and State practice pertaining to sovereign immunities, nor any State's rights with respect to its State vessels and aircraft."

47. Ronzitti Report, supra note 11 at 159 .

48. Ibid; although also pointing out (at 160) that for some states (e.g., Greece and Colombia) the provisions of the Convention on the rights of the coastal state were too weak. See also Dromgoole, supra note 15 at 154-165.

49. UCH Convention, supra note 8, Article 33.

50. Rule 1 of the UCH Convention, supra note 8.

51. Ibid, Rules $3 \& 4$.

52. Ibid, Rules 9-13.

53. Ibid, Rules $22 \& 23$.

54. Ibid, Rules $24 \& 25$.

55. Ibid, Rules $30 \& 31$.

56. Ibid, Rules 32-34.

57. Dromgoole, supra note 15 , at 57-58.ICOMOS is an international non-governmental organization that works for the conservation and protection of cultural heritage places, online: <https://www.icomos.org/en>.

58. UCH Convention, supra note 8, Article 33.

59. Dromgoole, supra note 15 at 58 (references omitted); and to the same effect see Roberts, supra note 22 at 838 .

60. Dromgoole, supra note 15 at 59.

61. On the concept of "verifiable link" see Dromgoole, supra note 15 at 127-132.

62. For further discussion see Roberts, supra note 22 at 846-854.

63. As with the discussion of the UCH Convention and given the location of the Erebus and Terror, the following paragraphs focus on sunken state ships located in waters under the sovereignty of the coastal state rather than such vessels when located in the Exclusive Economic Zone, the extended shelf, or the Area.

64. It bears repeating (see supra note 9) that the IDI resolution has no formal status in international law other than as an expression of the considered opinion of a group of eminent scholars and practitioners of international law.

65. IDI Tallinn Resolution, supra note 11, the opening words of Article 3.

66. Ibid, Article 7.

67. Ibid. Article 14 achieves this result by making the flag state's obligation "Subject to Article 7."

68. Ibid, Article 14(2). 
69. Ronzitti, Tallinn Session, supra note 11 at 300. The reference to "circumstances precluding wrongfulness" is a reference to Part One, Chapter V of the ILC's Draft Rules on the Responsibility of States for Internationally Wrongful Acts (2001), online: $<$ http://legal.un.org/docs/?path=../ilc/texts/instruments/english/draft articles $/ 96$ 2001.pdf\&lang=EF $>$.

70. IDI, Tallinn Resolution, supra note 10, Article 2(3).

71. Article 6(1) of the UCH Convention expressly encourages states to enter into bilateral as well as regional and other multilateral agreements pertaining to $\mathrm{UCH}$.

72. Memorandum of Understanding Between Great Britain and Canada Pertaining to the Shipwrecks HMS Erebus and HMS Terror, 5 \& 8 August 1997, online: <https:// assets.publishing.service.gov.uk/government/uploads/system/uploads/attachment data/file/458500/MOU FOI 0286-15.pdf>.

73. Deed of Gift made the 26 day of April 2018 Between the Secretary of State for Defence of the United Kingdom of Great Britain and Northern Ireland and the Parks Canada Agency, on file with the author, 3 pp, plus Annex A, 8 pp containing a list of artefacts from HMS Erebus excepted out of the gift of property.

74. Memorandum of Understanding Between the Secretary of State for Defence of the United Kingdom of Great Britain and Northern Ireland and the Parks Canada Agency for HMS Erebus and HMS Terror, 27 March 2018 and 26 April 2018, on file with the author, 4 pp.

75. RSC 1985, c H-4. Designation date 6 November 1992, Wrecks of HMS Erebus and HMS Terror, online: Parks Canada <https://www.pc.gc.ca/apps/dfhd/page nhs eng.aspx?id=334>. See also Dromgoole, supra note 15 at 142.

76. For example, in the course of efforts to obtain copies of these agreements (surprisingly difficult-but that's the subject of another article), the Director, Archaeology and History Branch, Parks Canada in an email (11 June 2018 on file with the author) indicated that "we [i.e., the Government of Canada] have released the $1997 \mathrm{MOU}$ as well given it isn't a legally binding agreement." I have no idea why the MOU should be more releasable because government officials consider it not to be legally binding-I would have thought that the reverse was at least equally plausible; but my point here is simply that there is evidently at least some opinion within the Government of Canada that considers that the MOU is not legally binding.

77. For a recent arbitral award dealing with the characterization of an agreement see South China Sea, Award on Jurisdiction and Admissibility, 29 October 2015, PCA Case No. 2013-19 at paras 212-219 and see also Maritime Delimitation in the Indian Ocean (Somalia v Kenya) Preliminary Objections [2017] ICJ Rep 3 at paras 36-50 concluding that a MOU between the parties was a valid treaty binding on the Parties under international law. For discussion in the literature see, amongst others, Duncan B Hollis, "Defining Treaties" in Duncan B Hollis, ed, The Oxford Guide to Treaties (Oxford University Press, 2012) 13 at 19-28; Anthony Aust, "Alternatives to TreatyMaking: MOUs as Political Commitments" in Hollis, The Oxford Guide to Treaties, ibid at 46, noting that "Calling an instrument a Memorandum of Understanding does not, in itself, determine its status, since — and most confusingly—some treaties 
are also called Memorandums of Understanding." Incidentally, Aust also suggests (at 47) that one reason for negotiating a political MOU rather than a binding agreement is if the parties wish to maintain confidentiality. Dromgoole, supra note 15 at $140-142$, while acknowledging that agreements pertaining to naval vessels may take different forms not all of which may be legally binding as treaties, takes no position on the status of the Erebus and Terror MOU.

78. Vienna Convention on the Law of Treaties, supra note 32.

79. Hollis, supra note 77 at 27.

80. VCLT, supra note 32, Article 26.

81. Some might refer to the fact that the UK has entered into other agreements relating to vessels in the form of an exchange of notes and has registered those agreements as treaties with the United Nations under the terms of Article 102 of the Charter of the United Nations. See, for example, Exchange of Notes Constituting an Agreement between the Government of the United Kingdom of Great Britain and Northern Ireland and the Government of Italy Regarding the Salvage of HMS Spartan, 6 November 1952, 158 UNTS 431, Rome, and Exchange of Notes Constituting an Agreement between the Government of the United Kingdom of Great Britain and Northern Ireland and the Government of the Republic of South Africa concerning the regulation of the terms of settlement of the salvaging of the wreck of HMS Birkenhead, 22 September 1989, 1584 UNTS 321, Pretoria. But compliance with Article 102 is a not a precondition to the categorization of an agreement as a treaty. Compliance with Article 102 may be some evidence that the party registering the agreement considers that it is a treaty but the failure to register by either party is much more equivocal as to the status of the agreement.

82. 1997 MOU, supra note 72 at para 2.

83. Ibid at para 3 .

84. There is a similar provision in the exchange of notes pertaining to the Birkenhead, supra note 81.

85. 1997 MOU, supra note 72 at para 4.

86. Ibid at para 6 .

87. Ibid at para 6 .

88. Ibid at para 7 .

89. In a statement in the House of Commons (UK) on 23 October 2017, indicated that the UK Government intended to replace the 1997 MOU "with an appropriate updated MOU.” See http://www.ukpol.co.uk/michael-fallon-2017-statement-onfranklin-wrecks/. However, the 2018 MOU, supra note 74, "recognizes" the 1997 and does not purport to terminate it. Quaere whether it could do so in any event considering that the 1997 MOU operates within international law while the 2018 agreement certainly does not.

90. Dromgoole, supra note 15 at 340. For the Agreement re the Birkenhead see supra note 81.

91. Deed of Gift, supra note 73. 
92. 2018 MOU, supra note 74. The 2018 MOU “recognizes" both the earlier MOU and the Deed of Gift.

93. Deed of Gift, supra note 73.

94. Ibid at paragraph 2.4 stipulates that "This deed is binding on the Parties and their respective successors and assigns."

95. Deed of Gift, supra note 73 at para 6.

96. Ibid at para 2.2 (emphasis added).

97. The Annex is headed "List of Artefacts - HMS Erebus - January 2018"; most of the items are single items except for a collection of bird shot and percussion caps.

98. Recall that para 2 of the 1997 MOU, supra note 72, recognized the primacy of Britain's ownership interest.

99. Ibid at para 4.1. "Government" is defined as "the Government of Canada or the Government of Nunavut or both."

100. Ibid at paras 4.2 and 4.3 .

101. Ibid at para 4.4 .

102. Perpetuities and Accumulations Act 2009 (UK), online: <https://www.bailii.org/uk/ legis/num act/2009/ukpga 20090018 en $1 . \mathrm{html}$.

103. 2018 MOU, supra note 74 at paras 4-7.

104. In response to an access to information request (18 July 2018) the UK's Ministry of Defence indicated that the Deed of Gift and "supporting MOU" were drafted taking into consideration the $1997 \mathrm{MOU}$ "but ensuring that certain conditions were included to ensure that the wrecks and artefacts are appropriately protected." The release went on to note that while neither Government was bound by the $\mathrm{UCH}$ Convention "both abide by the spirit of it's (sic) internationally accepted principles and guidelines.” https://assets.publishing.service.gov.uk/government/uploads/ system/uploads/attachment data/file/757667/06983 1.pdf.

105. It is not clear whether the three-year clock runs afresh after the eightieth anniversary of the deed or whether one counts prior periods of bailments together with periods post-2098. But it will be a long time before we need to resolve that question.

106. Paragraph 16 refers to the Guidance for Best Practice for the Treatment of Human Remains Excavated from Christian Burial Grounds in England (2017), online: <http:// www.archaeologyuk.org/apabe/pdf/APABE ToHREfCBG FINAL WEB.pdf>.

107. 2018 MOU, supra note 74 at para 16.

108. Deed of Gift, supra note 73 at para 6.

109. See Stephen Pitel \& Nicholas Rafferty, Conflict of Laws, 2nd ed (Toronto: Irwin Law, 2016) c 10, "The Choice of Law Process."

110. For Canada see SM Waddams, The Law of Contracts, 6th ed (Toronto: Canada Law Book, 2010) c 3. For England see Edwin Peel, Treitel on The Law of Contract, 13th ed (London: Sweet and Maxwell, 2011) c 4.

111. I do not consider here questions of state immunity that might well arise. If an action were brought in Canada see State Immunity Act, RSC 1985, c S-18, online: < $\underline{\mathrm{http}: / /}$ canlii.ca/t/lgij>. If the action were brought in England see State Immunity Act 1978, c 33, online: <http://www.legislation.gov.uk/ukpga/1978/33>. 
112. Oceans Act, SC 1996, c 31, online: <http://canlii.ca/t/52f10> s. 6: "The internal waters of Canada consist of the waters on the landward side of the baselines of the territorial sea of Canada." Canada drew straight baselines around the Arctic Archipelago in 1985, Territorial Sea Geographical Coordinates (Area 7) Order, SOR/85-872, online: <http://canlii.ca/t/18bd >.

113. Nunavut Act, SC 1993, c 28, online: <http://canlii.ca/t/53g90> defines Nunavut in part as "all that part of Canada north of the sixtieth parallel of north latitude." The internal waters of Canada are "part of Canada."

114. Nunavut Agreement, supra note 7.

115. RSC 1985 c H-4. Designation date November 6, 1992, Wrecks of HMS Erebus and HMS Terror, online: <https://www.pc.gc.ca/apps/dfhd/page nhs eng. aspx? $\mathrm{id}=334>$.

116. Ibid, emphasis added. The "address" is listed as Queen Maud Gulf, King William Island, Nunavut.

117. Order Amending the National Historic Sites of Canada Order, SOR/2015-88, 8 April 2015, online: <http://www.gazette.gc.ca/rp-pr/p2/2015/2015-04-22/html/ sor-dors88-eng.html>.

118. Order Amending the National Historic Sites of Canada Order, SOR/2017-273, 8 December 2017, online: <http://www.gazette.gc.ca/rp-pr/p2/2015/2015-04-22/ html/sor-dors88-eng.html>.

119. SC 2000, c 32. Section 42 of the Act allows the Governor in Council to "set apart any land, the title to which is vested in Her Majesty in right of Canada, as a national historic site of Canada to which this Act applies in order to ... (b) preserve a historic landmark, or any object of historic, prehistoric or scientific interest, that is of national importance."

120. Specifically Canadian National Parks Act ss 8(1), 12, 16(1)-16(3), 17-23, 24(2) \& (3) and 25-32.

121. National Historic Parks General Regulations, SOR/82-263, online: <https://laws-lois. justice.gc.ca/eng/regulations/sor-82-263/index.html>.

122. Superintendent's Order, Restricted area and activities in The Wrecks of HMS Erebus and HMS Terror National Historic Site of Canada, online: <https://www.pc.gc.ca/ en/lhn-nhs/nu/epaveswrecks/info/plan>.

123. First Nation of Nacho Nyak Dunv Yukon, [2017] 2 SCR 576, 2017 SCC 58 (CanLII), $<$ http://canlii.ca/t/hp2d8>.

124. Nunavut Agreement, supra note 7, s 9.1.1.

125. Ibid, s 8.4.4. Section 9.4.1 incorporates by reference the IIBA provisions from Chapter 8, Parks. Schedule 8-3 contains an indicative list of matters that might be appropriate for inclusion in an IIBA.

126. Emphasis added. The Agreement provides as an example the need to establish a critical wildlife area.

127. 2015 Order and RIAS, supra note 2.

128. 2017 Order and RIAS, supra note 118.

129. Ibid. 
130. Nunavut Agreement, supra note 7, s 9.3.2 and s 9.3.7 incorporating by reference ss 8.4.11 \& 12 .

131. Ibid, s 9.3.5. That is to say the provisions of any land use plan do not apply to these federally protected areas.

132. Nunavut Planning and Project Assessment Act, SC 2013, c 14, online: <https://lawslois.justice.gc.ca/eng/acts/N-28.75/>.

133. Nunavut Planning Commission letter to Nunavut Impact Review Board, 17 July 2017. The project file (NPC File No 148618) can be accessed on the NPC's website, online: $<$ https://www.nunavut.ca $>$.

134. See Nunavut Planning and Project Assessment Act s 92(1)(a) and 92(2)(a). The project file (No 17UN066) can be accessed on NIRB's website, online: $\langle$ https://nirb.ca $>$.

135. Nunavut Archaeological and Palaeontological Sites Regulations, SOR/2001-220, online: $<$ http://canlii.ca/t/16cw $>$.

136. Nunavut Act, supra note 113. The relevance of these regulations and therefore the interest of the Nunavut Government was recognized in yet another MOU, this time between the Government of Canada and the Government of Nunavut respecting Cooperation and Coordination for Research, Search, and Preservation Activities pertaining to the Shipwrecks HMS Erebus and HMS Terror and associated submerged archaeological resources, 14 and 21 August 2012, on file with the author. The MOU was signed before the discovery of either wreck. The MOU is a relatively "soft" agreement dealing with cooperation and coordination. Perhaps the most significant provision is a recital to the effect that "WHEREAS Nunavut has authority under the Nunavut Act and the Nunavut Archaeological and Palaeontological Sites Regulations for the protection of archaeological sites in all of the lands and waters under its jurisdiction."

137. Nunavut Act, supra note 113, Article 33.4.

138. See the webpage of the trust, under the heading "Trustees": <http://www.ihti.ca/ eng/home-english.html>.

139. Nunavut Archaeological and Palaeontological Sites Regulations, supra note 135.

140. See the Department's website, https://www.gov.nu.ca/culture-and-heritage/ information/archaeology-and-palaeontology, and see also Douglas Stenton, Guidelines for Applicants and of Nunavut Territory Archaeology and Paleontology Permits (2003), online: <https://www.gov.nu.ca/sites/default/files/files/Guide English.pdf>.

141. National Historic Parks General Regulations, supra note 121.

142. Nunavut Agreement, supra note 7, s 33.1.2.

143. The RIAS, supra note 118 notes that “... the tragedy of the Franklin Expedition echoes throughout Inuit oral history, and so the story of the expedition and the rescue attempts that followed are as much a part of Inuit history as they are a part of Canadian and British history."

144. See News Release, "Government of Canada confirms wreck of HMS Terror and deepens collaboration with Inuit in Nunavut through co-ownership of Franklin Artifacts," 16 September 2016, online: Parks Canada <https:/www.pc.gc.ca/en/ culture/franklin/communiques-franklin-releases>. 
145. News Release, 16 April 2019, "Government of Canada and Inuit Heritage Trust Sign Franklin Artifact Memorandum of Understanding Jointly-owned artifacts from HMS Erebus and HMS Terror will be protected and shared for the benefit of Inuit and all Canadians,” online: Parks Canada <https://www.pc.gc.ca/en/culture/ franklin/communiques-franklin-releases $>$. At the time of writing I have not been able to obtain a copy of this agreement.

146. Nunavut Agreement, supra note 7, s 33.7.4. "Designated Agency" is defined in terms of the agencies listed in Schedule 33-1 including the Canadian Museum of Civilization and the Canadian Parks Service.

147. Ibid, s 33.7 .5 (as amended).

148. Ibid, s 33.7.7.

149. Ibid, s 33.8.1.

150. Ibid, s 33.8.2.

151. Others, in a somewhat different context, have also remarked on the plurality of legal orders that are engaged by discussions of cultural heritage. See generally, Francesco Francioni, "Plurality and Interaction of Legal Orders in the Enforcement of Cultural Heritage Law" in Francesco Francioni and James Gordley, eds, Enforcing International Cultural Heritage Law (Oxford: Oxford University Press, 2013) 9.

\section{Acknowledgements}

Thanks to Kristen van de Biezenbos, Laurie Pelly, William MacKay, and two anonymous reviewers for helpful comments on earlier versions of this paper, and to Deanna McLeod for her careful editing. I am of course responsible for any remaining errors.

\section{Author}

Nigel Bankes is professor and Chair of Natural Resources Law in the Faculty of Law, The University of Calgary, and adjunct professor, KG Jebsen Centre for the Law of the Sea, UiT, the Arctic University of Norway. 